\title{
Three-Stage Dynamic Games of Government-Park-Visitor in Visitor Education Intervention
}

\author{
Dongping Wei, ${ }^{1,2}$ Shouwen Wen, ${ }^{3}$ Diabate Ardjouman, ${ }^{2}$ and Yizeng Chen ${ }^{2}$ \\ ${ }^{1}$ Math and Physics Department, Shenzhen Polytechnic, Shenzhen 518055, China \\ ${ }^{2}$ School of Management, Shanghai University, Shanghai 200444, China \\ ${ }^{3}$ School of Management, Shenzhen Polytechnic, Shenzhen 518055, China \\ Correspondence should be addressed to Shouwen Wen; wsw@szpt.edu.cn
}

Received 24 February 2014; Revised 4 July 2014; Accepted 6 July 2014; Published 13 August 2014

Academic Editor: Jinyun Yuan

Copyright (C) 2014 Dongping Wei et al. This is an open access article distributed under the Creative Commons Attribution License, which permits unrestricted use, distribution, and reproduction in any medium, provided the original work is properly cited.

\begin{abstract}
The government-park-visitor three-stage multiplayers dynamic game $G\left(S_{1}^{m}, S_{2}^{n}, S_{3}^{k}, R_{G}, R, U\right)$ is established to solve the significant problem regarding the investment in the visitor education. The game reveals that the visitor education intervention should form a positive interaction mechanism of government leading, tourism enterprise implementing, and tourist participating. The visitor education system in the tourism market has not been established at the initial stage. Stakeholders are hesitant to invest resources to push the establishment of visitor education system. The government should set up an induction fund which can encourage the parks and tourism companies to invest money on visitor education. When visitor education system develops to a certain stage with the help of government induction fund, it can run autonomously without the external factors. And the win-win-win situation of the government, parks, and visitors is obtained when the Nash equilibrium state of the game is reached. Furthermore, the game also reveals that visitor education mainly includes the behavior intervention and knowledge services which are important for the park's visitor education.
\end{abstract}

\section{Introduction}

The domestic tourists reached 2.9 billion in China in 2012 . As a result, this huge number of tourists puts tremendous pressure on the natural ecological environment and leads to a very fast rate of degradation. $22 \%$ of nature protection areas are damaged by the increasing tourist activities and $11 \%$ of tourism resources are degraded in China [1]. It is common to observe unwanted behaviors such as speaking loudly in public places, scratching some Chinese characters in landmarks of the tourism areas, and dumping garbage optionally. The unwanted behaviors of Chinese tourists are reported and criticized by Chinese and other countries media. Many scholars, researchers, and public policy departments are increasingly recommending an enhanced education in the tourism sector [2]. Studies and themes related to this subject not only have given rise to controversial debate but are also increasingly becoming popular. In May 2013, The State Council of China held a teleconference to discuss the implementation of the Tourism Law of the People's Republic of China. The Vice
Premier Wang-Yang pointed out that the abrasive behavior of tourists ruined the Chinese global images and continued to urge that these discourteous behaviors should be controlled. $\mathrm{He}$ also mentioned that enhancing the increase of public awareness and education which leads to enlightened and cultured Chinese tourists is the joint responsibility of all levels of government and their respective departments. The meeting is considered a clear landmark in the Chinese government's policy decision efforts to reinforce education in the tourism industry.

Tourism education systems have their origins in the United States. In 1979, the wilderness specialist Jim Bradley proposed a tourism education programme to reduce the negative impacts on nature reserve areas $[3,4]$. In the 1990s, the related department of the United States and a nonprofit organization designed and promoted a Leave No Trace [5] programme together. A similar Leave No Trace programme has already been implemented in many other western countries [6]. It must be noted that China attaches significant importance to visitor education. The "civilization" 
department of the central government and China National Tourism Administration issued Chinese Citizens Outbound Tourism Behavior Guidelines and Chinese Citizens Domestic Tourism Convention on Acceptance Standard Behavior in 2006. The two guidelines provided the Chinese population the basic requirements of civilized tourism. In 2012, the China National Tourism Administration released the fifth caution of the tourism sector that requires Chinese tourists to maintain and observe proper tourist etiquette when they visit tourist destinations. Behaving in a civilized manner and propriety of language should become the conscious actions of Chinese tourists. (The 2013 Tourism Law of the People's Republic of China advocates proper decorum and clearly forbids uncivilized behavior.) On the whole, the contents, patterns, and methods of visitor education have been studied and practiced fruitfully. However, the complete theoretical system, practice pattern, dynamic mechanism, and share responsibility for the education cost are the manifested bottlenecks.

Visitor education intervention is a complex system. A benign and health development of visitor education is based on tradeoff between ideal value and actual output. Not all of the stakeholders are willing to invest resources into visitor education because of their selfish motives. For example, some tourism resources are not pure public good and their spillover effect has specific region and direction. So governments are not willing to be a sole party to share the cost of visitor education [7]. Regarding the management of parks, they not only need to input human, material, and financial resources, but also need to take a risk including losing customers and triggering social conflicts due to intervening visitors' unwanted behaviors. When ignoring some visitors' uncivilized behaviors, the tourism resources will be degraded and possibly extinct. The benefit of government and parks will be reduced in that case. The public will lose the opportunities to visit precious tourist destination. Hence, whether the visitor education programme can be carried out effectively or not, it is the game between government, parks managers, and visitors.

In recent years, game theory has been widely applied to different disciplines in China. A few scholars started to apply game theory to study tourism management since 2004. For example, Li et al. applied game theory to analyse quantitatively the reasons of low price competition between two tourism companies in 2010 [8]. In 2011, Yang applied multielement dynamic game to study tourism industry management institutional change mechanism in China [9]. Because the time of visitor education programme development is short, there are few studies of input mechanism. The relative studies focus on environment protection and tourism destination development. For example, Yangping analyzed the behaviors of tourism companies when they were planning and implementing ecotourism policies and strategies. She finds the equilibrium strategies of governments and enterprises [10]. Liang used evolution game theory to analyse the complex relationships between governments and enterprises on account of environment protection. The relationships mutually promote and constrain each other. He considered the behaviors in environment protection of governments and enterprises as dynamic repeated game [11].
In 2013, Wang studied the multiplayer game between core stakeholders including governments, communities' residents, and visitors in tourism development of heritage sites of villages [12]. The core stakeholders adopt different actions in order to realize their own benefits. Wang set up a twostage game to analyse the mutual relations and mode of action between the stakeholders. And there is no scholar to study game between stakeholders on account of visitor education. So there are a few references about visitor education. Hence, it is important to apply game theory to study the cost share of visitor education in tourism management research. And it is also useful to explore tourism management policy.

This paper proposes the three-stage complete information multiplayers dynamic game between visitors, local governments, and parks managers to study the cost share of visitor education [13]. The models point out which party should invest money on visitor education and the ratio of investment. The models also propose an approach to calculate the benefit of visitor education. And the models can determine whether the players can gain maximization of benefits or not. The study tries to explore the cost sharing problem of visitor education.

\section{Definitions and Notations}

2.1. Profit Function of Visitors. The first primary mission of visitor education is to intervene in the visitors' behaviors based on the aims of parks' management, referred to as "behaviors intervening." The second primary mission is spreading or sharing knowledge of parks with visitor, referred to as "knowledge services." The unit cost of behavior intervening is denoted as $e_{1}$. And the unit cost of knowledge services is denoted as $e_{2}$. Then the total cost of visitor education is $e=\sum_{i=1}^{2} e_{i}$.

Visitors can gain the experience and enjoyment in tourism destination. The experience and enjoyment can be defined as the main benefit of visitors. The tourist satisfaction is considered the primary index of visitors' benefit for simplicity. A lot of researches demonstrated that the visitor education can promote the vast majority of visitors' satisfaction because it can effectively maintain the natural resources and social order in tourism destination [14]. The utility function of visitor satisfaction is defined as $u_{1}\left(x_{1} e_{1}\right)$, where $x_{1}$ is the visitors participation level of behaviors intervention. Visitors can choose the participation level according to their own need.

However, there is negative utility for minority visitors when they reduce unwanted behaviors. For example, the carrying of garbage time is increased because of the prohibition of littering. Then the visitors' satisfaction decreases when they feel inconvenience. The negative utility function is $g\left(x_{1} e_{1}\right)$.

The knowledge services provide visitors the unique learning resources including natural and humanities connotation in tourism destination. It can satisfy the knowledge desiring of visitors. So the satisfaction of visitors can increase because of effective knowledge services. The visitors' participation level according to their own requirement is $x_{2}$. The visitors' satisfaction increment due to knowledge services is $u_{2}\left(x_{2} e_{2}\right)$. The cost of basic services provided by parks can be defined as 
$c$. The visitors' satisfaction of the basic services is denoted as $u(c)$. Hence, the utility function of visitors can be denoted as follows:

$$
U\left(x_{1}, x_{2}\right)=u(c)+\sum_{i=1}^{2} u_{i}\left(x_{i} e_{i}\right)-g\left(x_{1} e_{1}\right)-f(a)
$$

where $a$ is the ticket price of park. The visitors' satisfaction does not decrease when the ticket is priced in a reasonable range; otherwise the satisfaction decreases. The tourist quantity increases when visitors' satisfaction increases. The function of tourist quantity can be described as follows:

$$
N=N\left(U\left(x_{1}, x_{2}\right)\right)
$$

2.2. Utility Function of Government. Generally, governments stand for public interests. Governments collect taxes as operating costs to provide policy services and industry supervision for tourism enterprises. In fact, visitor education services have some properties of public good. On the one hand, the parks have the responsibilities and obligations to provide visitor education service. On the other hand, governments also have a part of responsibilities to provide visitor education services. Government collects $t$ taxes on each ticket. Government pays $\alpha$ percentages of the total cost of visitor education. Then the earnings of government are

$$
R_{G}=(t-\alpha e) N\left(U\left(x_{1}, x_{2}\right)\right) .
$$

2.3. Earnings of Parks. Parks can save a part of resource maintenance and clean-keeping cost by the behavior intervention. The cost saving can be denoted as $\varphi\left(x_{1} e_{1}\right)$. In recent years, a lot of tourism companies and park managers in the USA, Australia, Hong Kong, and Taiwan employ professionals like professors or doctors as tour guides or interpreters. The excellent and vivid interpretation of the professionals has already become the magic key to attracting visitors especially repeating visitors. Hence, the knowledge services can save a part of market promotion cost. The part of cost saving is denoted as $\phi\left(x_{2} e_{2}\right)$. So the total incomes of park with $N$ tourists in a certain accounting cycle can be calculated as follows.

Gate receipts - basic services cost - visitor education cost + saving cost by visitor education - taxes.

The total income can be described as in the following equation:

$$
\begin{aligned}
R= & \left(a-c-\sum_{i=1}^{2} e_{i}+\varphi\left(x_{1} e_{1}\right)+\phi\left(x_{2} e_{2}\right)+\varepsilon-t+\alpha \sum_{i=1}^{2} e_{i}\right) \\
& \times N\left(u\left(x_{1}, x_{2}\right)\right)
\end{aligned}
$$

where $\varepsilon$ is submitted to distribution density function $f(\varepsilon)$ and $E(\varepsilon)=0$. The total cost saving by behavioral intervention and knowledge services is uncertain. Equation (4) can be transformed as follows:

$$
\begin{aligned}
R=(a & -c-(1-\alpha) \sum_{i=1}^{2} e_{i}+\varphi\left(x_{1} e_{1}\right) \\
& \left.+\phi\left(x_{2} e_{2}\right)+\varepsilon-t\right) N\left(u\left(x_{1}, x_{2}\right)\right),
\end{aligned}
$$

where $1-\alpha$ is the ratio of visitor education cost invested by the park. And $1-\alpha$ is smaller and smaller along with the larger visitor education subsidy of governments.

\section{Government-Park-Visitor Three-Stage Multiplayers Dynamic Game}

In fact, visitor education should be a matter of interaction by government, parks, and visitors. It is valuable to establish government-park-visitor three-stage multiplayers dynamic game to study the interaction between the three parties. In the first stage, regarding the government as a rational economic man, it should choose the optimal taxes ratio $t$ and input ratio of visitor education. In the second stage, the park mangers decide the optimal visitor education inputs $e_{1}$ and $e_{2}$ according to the taxes ratio and visitor education input ratio of government. In the third stage, visitors choose the optimal level of participation $\left(x_{1}, x_{2}\right)$ according to the visitor education input of park in order to gain the maximum satisfaction. The game $G\left(S_{1}^{m}, S_{2}^{n}, S_{3}^{k}, R_{G}, R, U\right)$ is complete and perfect information three-stage multiplayers dynamic game according to the analysis. $S_{1}^{m}, S_{2}^{n}$, and $S_{3}^{k}$ are the visitor education input strategy of government, parks, and visitors, respectively. $R_{G}$ is the earnings of government when providing tourism management services. $R$ is the earnings of parks when providing tourism services for visitors. $U$ is the satisfaction function of visitors. In the first stage of $G\left(S_{1}^{m}, S_{2}^{n}, S_{3}^{k}, R_{G}, R, U\right)$, government chooses the optimal strategy $(\alpha, t) \in S_{1}^{2}$ to maximize $R_{G}$. In the second stage of $G\left(S_{1}^{m}, S_{2}^{n}, S_{3}^{k}, R_{G}, R, U\right)$, park managers choose the optimal strategy $\left(e_{1}, e_{2}\right) \in S_{2}^{2}$ in order to maximize $R$ according to the strategy of government. In the third stage of $G\left(S_{1}^{m}, S_{2}^{n}, S_{3}^{k}, R_{G}, R, U\right)$, visitors choose the optimal strategy $\left(x_{1}, x_{2}\right) \in S_{3}^{2}$ in order to maximize $U$ according to the strategy of government and park managers. In fact, governmentpark-visitor three-stage multiplayers dynamic game can be expressed as in the following optimization problem:

$$
\begin{array}{ll}
\operatorname{Max} & \left\{R_{G}\left(\alpha, t, e_{1}, e_{2}, x_{1}, x_{2}\right), R\left(\alpha, t, e_{1}, e_{2}, x_{1}, x_{2}\right),\right. \\
& \left.U\left(\alpha, t, e_{1}, e_{2}, x_{1}, x_{2}\right)\right\} \\
\text { s.t. } & S_{1}^{m}=\left\{\alpha \in R^{m}, m=2\right\} \\
& S_{2}^{n}=\left\{e \in R^{n}, n=2\right\} \\
& S_{3}^{k}=\left\{x \in R^{k}, k=2,0 \leq x_{i} \leq 1\right\} .
\end{array}
$$




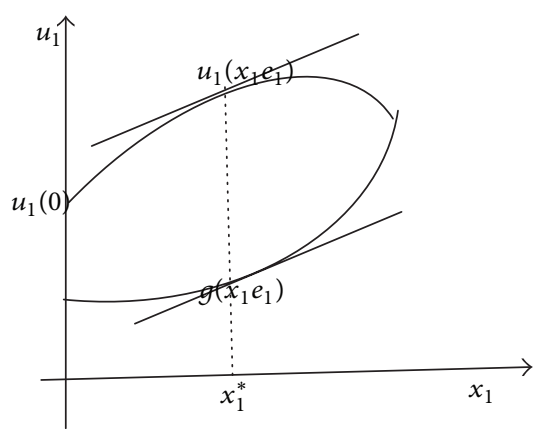

FIGURE 1: The utility function of visitor satisfaction due to behaviors intervention.

\section{The Nash Equilibrium Solution of the Game}

4.1. Optimal Strategy of Visitors. The backwards induction is the best method to explore the Nash equilibrium solution of the dynamic game [15]. As mentioned in Section 3, the parks managers provide the visitor education service including behaviors intervention and knowledge services. The unit visitor education cost is $e_{1}$ and the participation level of visitor is $x_{1}$. The possibility of reducing uncivilized behavior is higher if the participation level of visitor is higher. Then the cleanliness of the park and the completeness of the park's facilities are better. It is the positive effect of visitor education intervention. Figure 1 shows that $u_{1}(0) \leq u_{1}\left(x_{1} e_{1}\right) \leq u_{1}\left(e_{1}\right)$ and $u_{1}^{\prime}\left(x_{1} e_{1}\right) \geq 0, u_{1}^{\prime}\left(x_{1} e_{1}\right) \leq 0$.

As shown in Figure $1, u_{1}\left(x_{1} e_{1}\right)$ is convex function satisfying law of diminishing utility. In other words, the satisfaction level of visitors is higher when the participation level is higher given $e_{1}$. But the growth rate of the satisfaction is getting smaller.

On the other hand, there is negative effect when visitors reduce their unwanted behaviors, so the negative effects get higher when the participation level is higher. $g\left(x_{1} e_{1}\right)$ is concave function and satisfies $0<g(0) \leq g\left(x_{1} e_{1}\right) \leq$ $g\left(e_{1}\right)$ as demonstrated in Figure 1. $g\left(x_{1} e_{1}\right)$ means that visitors contradict the behavior intervention naturally. Especially the education method is rude such as fine, scold, threaten, or preach.

In addition to behavior intervention, knowledge services $e_{2}$ for visitors should be under the acceptable level. It should revise the visitors' characters and their tour goal. For example some tourists visited for the sake of relaxing, so too much preaching reduces their satisfaction on the contrary.

Hence, visitors rationally choose their participation level to obtain the optimal satisfaction level with specified knowledge service $e_{2} \cdot u_{2}\left(x_{2} e_{2}\right)$ satisfies $u_{2}^{\prime}\left(x_{2} e_{2}\right)>0$ and $u_{2}^{\prime \prime}\left(x_{2} e_{2}\right) \leq$ 0 , so $u_{2}\left(x_{2} e_{2}\right)$ is concave function. As shown in Figure 2 , the visitors' satisfaction increment due to knowledge services also satisfies law of diminishing utility. After the satisfaction level achieves the optimal level, if the visitors' participation level increases, then the tourist satisfaction decreases on the contrary.

In the third stage of government-park-visitor three-stage multiplayers dynamic game, visitors choose the optimal

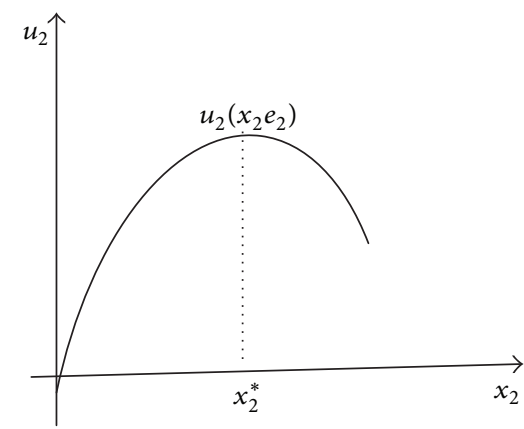

Figure 2: The visitors' satisfaction increment due to knowledge services.

participation level $\left(x_{1}, x_{2}\right)$ which is the solution of the following optimization problem:

$$
\begin{aligned}
\max \{U & \left.\left(\alpha, t, e_{1}, e_{2}, x_{1}, x_{2}\right)\right\} \\
& =\max _{0 \leq x_{1}, x_{2} \leq 1}\left\{u(c)+\sum_{i=1}^{2} u_{i}\left(x_{i} e_{i}\right)-g\left(x_{1} e_{1}\right)-f(a)\right\}
\end{aligned}
$$$$
\text { s.t. } \quad x=\left(x_{1}, x_{2}\right) \in S_{3}^{2} \text {. }
$$

The optimization first order condition of (7) is

$$
\begin{gathered}
\frac{\partial U\left(\alpha, t, e_{1}, e_{2}, x_{1}, x_{2}\right)}{\partial x_{1}}=u_{1}^{\prime}\left(x_{1}^{*} e_{1}^{*}\right)-g^{\prime}\left(x_{1}^{*} e_{1}^{*}\right)=0, \\
\frac{\partial U\left(\alpha, t, e_{1}, e_{2}, x_{1}, x_{2}\right)}{\partial x_{2}}=u_{2}^{\prime}\left(x_{2}^{*} e_{2}^{*}\right)=0 .
\end{gathered}
$$

Equation (8) shows that visitors choose the optimal participation level $x_{1}^{*}$ in the condition that marginal positive and negative utility of the behavior intervention are equal. In other words, visitors choose the last unit behavior intervention until the increment of satisfaction level is equal to the negative effect increment. In Figure $1, \Delta u=u_{1}\left(x_{1} e_{1}\right)-g\left(x_{1} e_{1}\right)$ obtains the maximum value when the slopes of $u_{1}\left(x_{1} e_{1}\right)$ and $g\left(x_{1} e_{1}\right)$ are equal. The optimal behavior intervention participation level of visitors is obtained at this moment.

Equation (9) indicates that visitors choose the optimal knowledge services participation level $x_{2}^{*}$ to gain the maximum satisfaction level $u_{2}\left(x_{2}^{*} e_{2}^{*}\right)$. The satisfaction level decreases on the contrary when participation level $x_{2}^{*}$ increases one unit. This is referred to as knowledge overload phenomenon [8]. The tourists' goal is not only gaining knowledge, but also entertainment and relaxation. In the third stage of government-park-visitor three-stage multiplayers dynamic game $G\left(S_{1}^{m}, S_{2}^{n}, S_{3}^{k}, R_{G}, R, U\right)$, the Nash equilibrium strategy of visitors $\left(x_{1}^{*}, x_{2}^{*}\right)$ can be solved with (8) and (9).

4.2. Optimal Visitors Education Strategy of Park Managers. In the second stage of government-park-visitor three-stage multiplayers dynamic game $G\left(S_{1}^{m}, S_{2}^{n}, S_{3}^{k}, R_{G}, R, U\right)$, park managers should choose the optimal visitor education investment 
$\left(e_{1}^{*}, e_{2}^{*}\right)$ in order to gain the maximum earnings. But equilibrium investment should satisfy the condition that visitors are willing to take part in the visitor education. It is so-called participation constraint of visitors. In fact, every visitor would like to relax and enjoy in the park. The initial expectation of satisfaction level is denoted as $U_{0}$.

The equilibrium investment $\left(e_{1}^{*}, e_{2}^{*}\right)$ should satisfy $U\left(x_{1}^{*}\right.$, $\left.x_{2}^{*}, e_{1}^{*}, e_{2}^{*}\right) \geq U_{0}$. As an economic man who chases benefit maximization, the park manager should choose $U\left(x_{1}^{*}\right.$, $\left.x_{2}^{*}, e_{1}^{*}, e_{2}^{*}\right)=U_{0}$. Consider

$$
u(c)+\sum_{i=1}^{2} u_{i}\left(x_{i}^{*} e_{i}^{*}\right)-g\left(x_{1}^{*} e_{1}^{*}\right)-f(a)=U_{0} .
$$

The tourist quantity is getting larger when visitors satisfaction level is becoming higher. For simplicity, the linear relation between the tourist quantity and visitor satisfaction level holds such as $N\left(U\left(x_{1}, x_{2}\right)\right)=w U+N_{0}$. But the tourist quantity should be controlled in a certain region. The tourist quantity $N_{\max }$ should not surpass the maximum capacity of the park; otherwise it can destroy the park. Meanwhile, the minimal tourist quantity should be required to maintain the basic operation. So the tourist quantity $N\left(U\left(x_{1}, x_{2}\right)\right)$ should satisfy the constraint $N_{\min } \leq N\left(U\left(x_{1}, x_{2}\right)\right) \leq N_{\max }$.

The park managers should choose the optimal visitor education investment $\left(e_{1}^{*}, e_{2}^{*}\right)$ to satisfy the following optimization problem in order to gain the maximum expectation return:

$$
\begin{array}{r}
\max \quad\left\{E R\left(\alpha, t, x_{1}^{*}, x_{2}^{*}, e_{1}^{*}, e_{2}^{*}\right)\right\} \\
=\max \left(a-c-(1-\alpha) \sum_{i=1}^{2} e_{i}^{*}+\varphi\left(x_{1}^{*} e_{1}^{*}\right)\right. \\
\left.+\phi\left(x_{2}^{*} e_{2}^{*}\right)-t\right) N\left(U\left(x_{1}^{*}, x_{2}^{*}\right)\right)
\end{array}
$$

$$
\begin{array}{ll}
\text { s.t. } & x^{*}=\left(x_{1}^{*}, x_{2}^{*}\right) \in S_{3}^{2} \\
& e^{*}=\left(e_{1}^{*}, e_{2}^{*}\right) \in S_{2}^{2} .
\end{array}
$$

For simplicity, $\widetilde{E R}\left(\alpha, t, x_{1}^{*}, x_{2}^{*}, e_{1}^{*}, e_{2}^{*}\right)=(a-c-(1-$ a) $\left.\sum_{i=1}^{2} e_{i}^{*}+\varphi\left(x_{1}^{*} e_{1}^{*}\right)+\phi\left(x_{2}^{*} e_{2}^{*}\right)-t\right)$.

Substituting $N\left(U\left(x_{1}, x_{2}\right)\right)$ into (11), we can calculate the optimization first order condition

$$
\begin{aligned}
\frac{\partial E R}{\partial e_{1}^{*}}= & \widetilde{E R}\left(\alpha, t, x_{1}^{*}, x_{2}^{*}, e_{1}^{*}, e_{2}^{*}\right) w \frac{\partial U\left(x_{1}^{*}, x_{2}^{*}\right)}{\partial e_{1}^{*}} \\
& +\left(\frac{\partial \varphi\left(x_{1}^{*} e_{1}^{*}\right)}{\partial e_{1}^{*}}-(1-\alpha)\right)\left(w U\left(x_{1}^{*}, x_{2}^{*}\right)+N_{0}\right)=0,
\end{aligned}
$$

$$
\begin{aligned}
\frac{\partial E R}{\partial e_{2}^{*}}= & \widetilde{E R}\left(\alpha, t, x_{1}^{*}, x_{2}^{*}, e_{1}^{*}, e_{2}^{*}\right) w \frac{\partial U\left(x_{1}^{*}, x_{2}^{*}\right)}{\partial e_{2}^{*}} \\
& +\left(\frac{\partial \phi\left(x_{2}^{*} e_{2}^{*}\right)}{\partial e_{2}^{*}}-(1-\alpha)\right)\left(w U\left(x_{1}^{*}, x_{2}^{*}\right)+N_{0}\right)=0,
\end{aligned}
$$

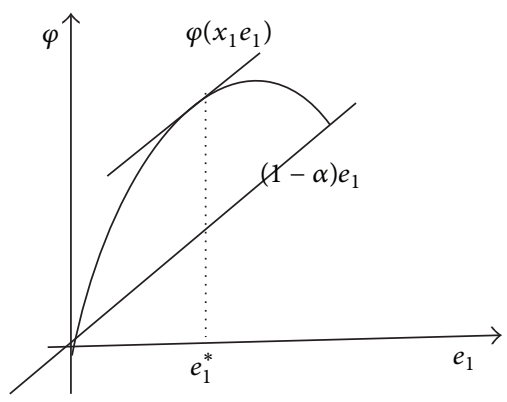

FIGURE 3: The optimizing visitors' participation strategy with behaviors intervention.

where

$$
\frac{\partial U\left(x_{1}^{*}, x_{2}^{*}\right)}{\partial e_{1}^{*}}=\frac{\partial u_{1}\left(x_{1}^{*} e_{1}^{*}\right)}{\partial e_{1}^{*}}-\frac{\partial g\left(x_{1}^{*} e_{1}^{*}\right)}{\partial e_{1}^{*}} .
$$

And we can get that

$$
\begin{gathered}
\frac{\partial u_{1}\left(x_{1}^{*} e_{1}^{*}\right)}{\partial e_{1}^{*}} e_{1}^{*}=\frac{\partial u_{1}\left(x_{1}^{*} e_{1}^{*}\right)}{\partial x_{1}^{*}} x_{1}^{*}, \\
\frac{\partial g\left(x_{1}^{*} e_{1}^{*}\right)}{\partial e_{1}^{*}} e_{1}^{*}=\frac{\partial g\left(x_{1}^{*} e_{1}^{*}\right)}{\partial x_{1}^{*}} x_{1}^{*} .
\end{gathered}
$$

Hence, we can obtain the following (17) with (12), (14), (15), and the optimal visitors' participation strategy (8):

$$
\frac{\partial \varphi\left(x_{1}^{*} e_{1}^{*}\right)}{\partial e_{1}^{*}}=(1-\alpha)
$$

And the following equation can be obtained by optimizing visitors' participation strategy $(8)$ and $\left(\partial U\left(x_{1}^{*}, x_{2}^{*}\right) / \partial e_{2}^{*}\right)=$ $\left(\partial u_{2}\left(x_{2}^{*} e_{2}^{*}\right) / \partial e_{2}^{*}\right)$ :

$$
\frac{\partial \phi\left(x_{2}^{*} e_{2}^{*}\right)}{\partial e_{2}^{*}}=(1-\alpha) .
$$

Equation (17) is the optimal park investment strategy of behavior intervention. Equation (17) shows that the marginal return of investment $e_{1}^{*}$ should be equal to the investment rate of the park. Figure 3 shows that the slope of the return curve of visitor behavior intervention of park should equal the slope of investment curve. The maximum return of the park's investment on visitor behavior intervention is obtained at this moment. Figure 4 shows that the slope of the return curve of the park's knowledge services should equal the slope of the investment curve. The maximum return of the park's investment on knowledge services is obtained at this moment.

Obviously, $\left(\partial \varphi\left(x_{1}^{*} e_{1}^{*}\right) / \partial e_{1}^{*}\right)=\left(\partial \phi\left(x_{2}^{*} e_{2}^{*}\right) / \partial e_{2}^{*}\right)=(1-\alpha)$ based on (17) and (18). The park's optimal investment strategy on visitor education should satisfy that the marginal return of investment on the behavior intervention is equal to the marginal return of investment on the knowledge services. The optimal visitor education investment strategy of the 


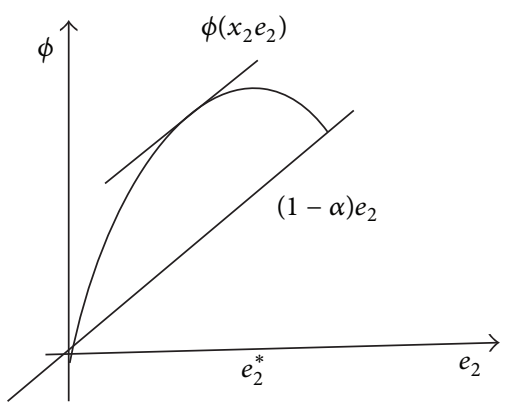

FIgURE 4: The optimizing visitors' participation strategy with knowledge services.

park $\left(e_{1}^{*}, e_{2}^{*}\right)$ can be solved from (8), (9), (10), (17), and (18) given the government's strategy $(\alpha, t)$. And the optimal visitors' participation level $\left(x_{1}^{*}, x_{2}^{*}\right)$ can be also obtained by the equations.

\subsection{Optimal Taxes and Visitor Education Investment Strategy.} In the third stage of government-park-visitor three-stage multiplayers dynamic game $G\left(S_{1}^{m}, S_{2}^{n}, S_{3}^{k}, R_{G}, R, U\right)$, visitors choose their own optimal participation strategy $\left(x_{1}^{*}, x_{2}^{*}\right)$ according to the park's investment strategy. In the second stage of the game, the park managers choose their optimal visitor education investment strategy according to the government's taxes and investment strategy and visitors' strategy. Backward to the first stage of the game, the government should choose an optimal strategy.

The government is referred to as an economic man who is chasing benefit maximization. On the other hand, visitor education has the properties of public good partly. Government should bear a part of visitor education investment for the sake of public interests and social welfare.

The government should firstly consider that the park managers are willing to invest money to operate the park when it is choosing the optimal taxes and visitor education investment strategy. In other words, the government should choose $\left(\alpha^{*}, t^{*}\right)$ to make the expectation return no less than the normal market profit rate. It can be referred to as the minimum participation constraint of the park, $E R\left(\alpha^{*}, t^{*}, x_{1}^{*}, x_{2}^{*}, e_{1}^{*}, e_{2}^{*}\right) \geq R_{0}$. So the minimum participation constraint equation (19) is obtained as follows:

$$
\begin{aligned}
& \left(a-c-\sum_{i=1}^{2} e_{i}^{*}+\varphi\left(x_{1}^{*} e_{1}^{*}\right)+\phi\left(x_{2}^{*} e_{2}^{*}\right)-t^{*}+\alpha^{*} \sum_{i=1}^{2} e_{i}^{*}\right) \\
& \times N\left(U\left(x_{1}^{*}, x_{2}^{*}\right)\right)=R_{0} .
\end{aligned}
$$

Hence, the government choice of the optimal taxes and visitor education investment strategy should satisfy the following maximization problem:

$$
\begin{aligned}
& \max \quad\left\{\left(t^{*}-\alpha^{*} \sum_{i=1}^{2} e_{i}^{*}\right) N\left(U\left(x_{1}^{*}, x_{2}^{*}\right)\right)\right\} \\
& \text { s.t. } \quad t=\left(t^{*}, \alpha^{*}\right) \in S_{1}^{2} .
\end{aligned}
$$

The following equation can be calculated by (19)

$$
\begin{aligned}
R_{G}= & \left(t^{*}-\alpha^{*}\right) \sum_{i=1}^{2} e_{i}^{*} N\left(U\left(x_{1}^{*}, x_{2}^{*}\right)\right)=N\left(U\left(x_{1}^{*}, x_{2}^{*}\right)\right) \\
& \times\left(a-c-\sum_{i=1}^{2} e_{i}^{*}+\varphi\left(x_{1}^{*} e_{1}^{*}\right)+\phi\left(x_{2}^{*} e_{2}^{*}\right)\right)-R_{0} .
\end{aligned}
$$

The maximization problem (20) can be transformed as follows from (21):

$$
\begin{aligned}
& \max _{e_{1}^{*}, e_{2}^{*}}\left\{N\left(U\left(x_{1}^{*}, x_{2}^{*}\right)\right)\right. \\
& \quad \times\left(a-c-\sum_{i=1}^{2} e_{i}^{*}+\varphi\left(x_{1}^{*} e_{1}^{*}\right)+\phi\left(x_{2}^{*} e_{2}^{*}\right)\right) \\
& \left.\quad-R_{0}\right\} \\
& \text { s.t. } \quad x^{*}=\left(x_{1}^{*}, x_{2}^{*}\right) \in S_{3}^{2} \\
& \quad e^{*}=\left(e_{1}^{*}, e_{2}^{*}\right) \in S_{2}^{2} .
\end{aligned}
$$

Letting $\widetilde{R}=a-c-\sum_{i=1}^{2} e_{i}^{*}+\varphi\left(x_{1}^{*} e_{1}^{*}\right)+\phi\left(x_{2}^{*} e_{2}^{*}\right)$, we can obtain the first order condition of the maximization problem (22):

$$
\begin{aligned}
\frac{\partial R_{G}}{\partial e_{1}^{*}}= & \left(\frac{\partial \varphi\left(x_{1}^{*} e_{1}^{*}\right)}{\partial e_{1}^{*}}-1\right) N\left(U\left(x_{1}^{*}, x_{2}^{*}\right)\right) \\
& +\widetilde{R} \frac{\partial N\left(U\left(x_{1}^{*}, x_{2}^{*}\right)\right)}{\partial e_{1}^{*}}=0, \\
\frac{\partial R_{G}}{\partial e_{2}^{*}}= & \left(\frac{\partial \phi\left(x_{2}^{*} e_{2}^{*}\right)}{\partial e_{2}^{*}}-1\right) N\left(U\left(x_{1}^{*}, x_{2}^{*}\right)\right) \\
& +\widetilde{R} \frac{\partial N\left(U\left(x_{1}^{*}, x_{2}^{*}\right)\right)}{\partial e_{2}^{*}}=0,
\end{aligned}
$$

where

$$
\begin{aligned}
\frac{\partial N\left(U\left(x_{1}^{*}, x_{2}^{*}\right)\right)}{\partial e_{1}^{*}} & =w \frac{\partial U\left(x_{1}^{*}, x_{2}^{*}\right)}{\partial e_{1}^{*}} \\
& =w\left(\frac{\partial u_{1}\left(x_{1}^{*} e_{1}^{*}\right)}{\partial e_{1}^{*}}-\frac{\partial g\left(x_{1}^{*} e_{1}^{*}\right)}{\partial e_{1}^{*}}\right), \\
\frac{\partial N\left(U\left(x_{1}^{*}, x_{2}^{*}\right)\right)}{\partial e_{2}^{*}} & =w \frac{\partial U\left(x_{1}^{*}, x_{2}^{*}\right)}{\partial e_{2}^{*}}=w \frac{\partial u_{1}\left(x_{2}^{*} e_{2}^{*}\right)}{\partial e_{2}^{*}} .
\end{aligned}
$$

Equations (26) and (27) can be obtained with (8), (9), (15), (16), (23), and (24):

$$
\begin{aligned}
& \frac{\partial \varphi\left(x_{1}^{*} e_{1}^{*}\right)}{\partial e_{1}^{*}}-1=0, \\
& \frac{\partial \phi\left(x_{2}^{*} e_{2}^{*}\right)}{\partial e_{2}^{*}}-1=0 .
\end{aligned}
$$




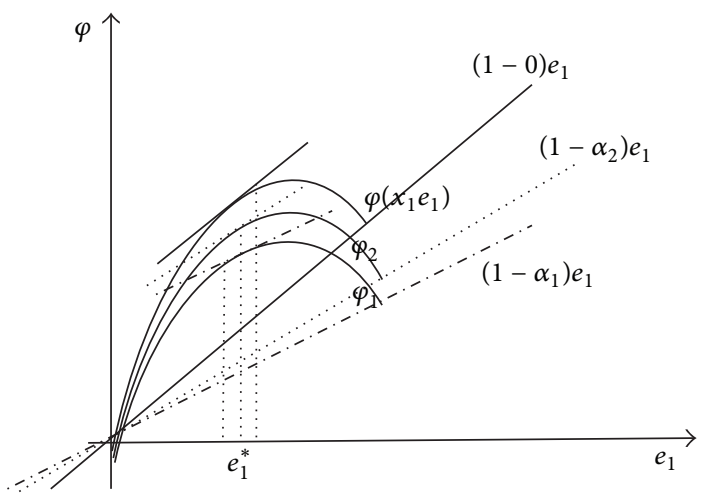

Figure 5: The effect on behaviors intervention by the government visitor education induction coefficient $\alpha$.

$\left(\partial \varphi\left(x_{1}^{*} e_{1}^{*}\right) / \partial e_{1}^{*}\right)=\left(\partial \phi\left(x_{2}^{*} e_{2}^{*}\right) / \partial e_{2}^{*}\right)=1$ can be derived from (26) and (27). And we can derive from $\left(\partial \varphi\left(x_{1}^{*} e_{1}^{*}\right) / \partial e_{1}^{*}\right)=\left(\partial \phi\left(x_{2}^{*} e_{2}^{*}\right) / \partial e_{2}^{*}\right)=(1-\alpha)$ that $\alpha=0$. $\alpha=0$ means that the government does not need to invest any visitor education fund when the multiplayers game achieves the Nash equilibrium state. The government can get the maximum profit at this moment. Equation $\left(\partial \varphi\left(x_{1}^{*} e_{1}^{*}\right) / \partial e_{1}^{*}\right)=$ $\left(\partial \phi\left(x_{2}^{*} e_{2}^{*}\right) / \partial e_{2}^{*}\right)=(1-\alpha)$ shows that $\alpha \neq 0$ and $\alpha>$ 0 when government-park-visitor three-stage multiplayers dynamic game $G\left(S_{1}^{m}, S_{2}^{n}, S_{3}^{k}, R_{G}, R, U\right)$ does not achieve the Nash equilibrium state. The government should invest a lot of funds to induce or support the park to develop visitor education.

So $\alpha$ is defined as a government visitor education induction coefficient. When the visitor education market is still at the initial or immature stage, the government should invest more funds $(\alpha \gg 0$ ) to support or induce the park to develop visitor education.

When the park managers gradually gain the benefit from visitor education, their investment enthusiasm is also improved continually. The visitor education steps into market operation stage driven by interest benefit. The government can reduce the visitor education investment gradually at this moment. The contents and methods of visitor education can be adjusted by the market mechanism. The visitors' satisfaction can also achieve the maximization state.

It is valuable to further study the effect of the government visitor education induction coefficient $\alpha$. The function form of $\varphi\left(x_{1} e_{1}\right)$ and $\phi\left(x_{2} e_{2}\right)$ can be changed by the coefficient $\alpha$ seen from Figures 5 and 6 . The leading investment to visitor education effect is larger when $\alpha$ is larger. In the initial stage, the game $G\left(S_{1}^{m}, S_{2}^{n}, S_{3}^{k}, R_{G}, R, U\right)$ can reach equilibrium state, but it is under lower equilibrium state. The investment enthusiasm of park is becoming higher and higher with the increase of positive effect of visitor education. The government intervention coefficient $\alpha$ decreases along with higher investment enthusiasm of the park. The equilibrium spot moves up slowly and the benefit of the park increases. Then the game $G\left(S_{1}^{m}, S_{2}^{n}, S_{3}^{k}, R_{G}, R, U\right)$ can reach higher equilibrium state. $\alpha$ diminishes to zero finally, so the government induction investment is ended and the government withdraws

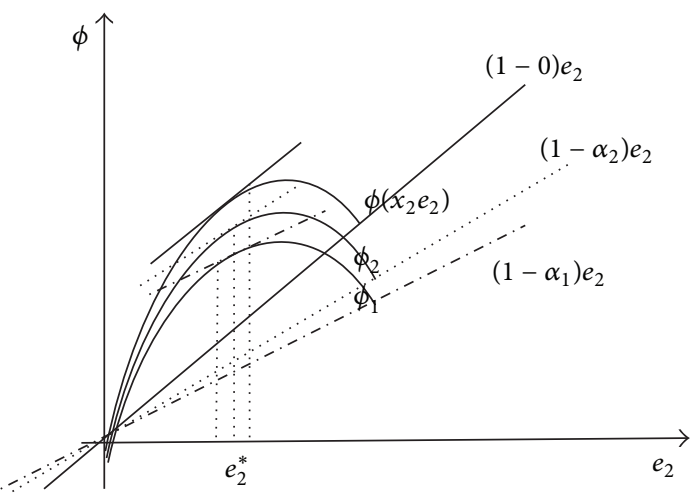

FIGURE 6: The effect on knowledge services by the government visitor education induction coefficient $\alpha$.

from the market. The park can autonomously invest through the market and the highest equilibrium is achieved. At this time, the park's visitor education investment achieves the maximum and the benefit of the visitors is also maximized.

The following equation can be got by (23):

$$
\widetilde{\varphi}^{\prime}\left(e_{1}^{*}\right)=\Delta \widetilde{u}^{\prime}\left(x_{1}^{*} e_{1}^{*}\right) \frac{\widetilde{R} w}{N\left(U\left(x_{1}^{*}, x_{2}^{*}\right)\right)},
$$

where $\Delta \tilde{u}^{\prime}\left(x_{1}^{*} e_{1}^{*}\right)=\left(\partial u_{1}\left(x_{1}^{*} e_{1}^{*}\right) / \partial e_{1}^{*}\right)-\left(\partial g\left(x_{1}^{*} e_{1}^{*}\right) / \partial e_{1}^{*}\right)$ denotes the marginal satisfaction increment brought by the park's investment on behavior intervention. $\widetilde{\varphi}^{\prime}\left(e_{1}^{*}\right)=1-$ $\left(\partial \varphi\left(x_{1}^{*} e_{1}^{*}\right) / \partial e_{1}^{*}\right)$ is the marginal return brought by the park's investment on behavior intervention.

The following equation can be calculated by (27):

$$
\gamma^{*}=\frac{\widetilde{\varphi}^{\prime}\left(e_{1}^{*}\right)}{\Delta \widetilde{u}^{\prime}\left(x_{1}^{*} e_{1}^{*}\right)}=\frac{w \widetilde{R}}{N\left(U\left(x_{1}^{*}, x_{2}^{*}\right)\right)},
$$

where $\gamma^{*}$ is park-visitor win-win coefficient generated by the park's investment on behavior intervention. $\widetilde{R}$ is the unit visitor's benefit. $w$ is the tourist quantity sensitivity coefficient of the park. $w$ is for sensitiveness between the tourist quantity of the parks and visitors' satisfaction.

Equation (29) represents that the government should make the park and visitor achieve win-win state when it is inducing the park to implement visitor behavior intervention. The park-visitor win-win coefficient is related to the tourist quantity, the tourist quantity sensitivity coefficient of the park, and the return of the park. It means that the maximized benefit of the park and the maximized satisfaction maximization of visitors should be considered, and the compatibility of the visitor quantity and the ecological environment should be also considered.

The following result can be obtained by (24):

$$
v^{*}=\frac{\widetilde{\phi}^{\prime}\left(e_{2}^{*}\right)}{{\widetilde{u_{2}}}^{\prime}\left(x_{2}^{*} e_{2}^{*}\right)}=\frac{w \widetilde{R}}{N\left(U\left(x_{1}^{*}, x_{2}^{*}\right)\right)},
$$

where $\widetilde{\phi}^{\prime}\left(e_{2}^{*}\right)=1-\left(\partial \phi\left(x_{2}^{*} e_{2}^{*}\right) / \partial e_{2}^{*}\right), \widetilde{u}_{2}^{\prime}=\left(\partial u_{2}\left(x_{2}^{*} e_{2}^{*}\right) / \partial e_{2}^{*}\right)$. $v^{*}$ is the park-visitor win-win coefficient generated by the park's investment on knowledge services. Equation (30) 
represents that the government should make the park and visitor achieve win-win state when it induces the park to implement knowledge services. It means that the maximized benefit of the park, the maximized satisfaction of visitors, and the compatibility of the visitor quantity and the ecological environment should be considered when the park provides visitor education.

The Nash equilibrium solution of the game $G\left(S_{1}^{m}, S_{2}^{n}\right.$, $\left.S_{3}^{k}, R_{G}, R, U\right)$ can be obtained by (8), (9), (15), (19), (26), and (27). And the win-win-win situation of the government, parks, and visitors appears on the Nash equilibrium state of the game. The three sides simultaneously gain the maximum benefit.

\section{Conclusion and Discussion}

This paper establishes a government-park-visitor three-stage multiplayers dynamic game $G\left(S_{1}^{m}, S_{2}^{n}, S_{3}^{k}, R_{G}, R, U\right)$ to solve the significant problem about the investment on the visitor education. The win-win-win situation of the government, parks, and visitors is obtained when the Nash equilibrium state of the game is reached. China should design the interactive mechanism of government-led enterprise orientation and visitor participation to establish the visitor education market. The government-park-visitor three-stage multiplayers dynamic game $G\left(S_{1}^{m}, S_{2}^{n}, S_{3}^{k}, R_{G}, R, U\right)$ can draw the following four conclusions in this paper.

(1) When the visitor education system in the tourism market is not established and there is no other external factor to push the establishment, visitor education can only gain the equilibrium in lower level. The park and visitors can gain the maximum profit in lower level. In that case, the government should set up induction fund to lead the parks and tourism companies to invest money on visitor education. The induction fund has the leverage and amplification effect. The return function of the park can be changed and the park can obtain the maximum profit in higher level. In Summary, we should guide and stimulate nongovernment investment on visitor education by means of well-leveraged government investment.

(2) Because the park is a rational economic man, it implements visitor education according to the principle of profit maximization. The visitor education can bring some profit to the park, but the profit is not large enough to push the development of visitor education. When visitor education develops to a certain stage with the help of government induction fund, it can run automatically without the external factors. And the game $G\left(S_{1}^{m}, S_{2}^{n}, S_{3}^{k}, R_{G}, R, U\right)$ can reach Nash equilibrium state in the autonomous running stage.

(3) The behavior intervention and knowledge services are important for the park's visitor education because they can bring the same return growth.

(4) The behavior intervention usually brings some negative effect to visitors. So the park managers should make the visitors recognize the positive effect to the environment brought by the behavior intervention. The visitor should know that the behavior intervention can bring them more comfort and satisfaction.

In addition, the knowledge service should notice the visitor education methods. The knowledge services should be under visitors' acceptable level. The knowledge services should integrate teaching with tourism and fun. The park managers should realize that too much knowledge services decrease the tourist satisfaction on the contrary. There is a parable that tells the truth: too much is as bad as too little.

\section{Conflict of Interests}

The authors declare that there is no conflict of interests regarding the publication of this paper.

\section{Authors' Contribution}

Dongping Wei and Shouwen Wen contributed equally to this work.

\section{Acknowledgments}

This work is supported by National Science Fund of China (Grant nos. 71272177/G020902, 31100958, and 11101434), Social Science Foundation of Guangdong (Grant no. GD13CGL16), Youth Innovation fund of Shenzhen polytechnic (Grant no. 601422K35018), the Project of Higher Vocational Education Research Society of China (Grant no. GZYLX1213345), and Shenzhen Education Society (Grant no. XH021). And the authors would like to thank the editor and the anonymous referee for their helpful comments on the manuscript.

\section{References}

[1] D. Wei, S. Wen, Y. Chen, Y. Xu, and B. Liang, "The stochastic dynamics for ecological tourism system with visitor educational intervention," Mathematical Problems in Engineering, vol. 2013, Article ID 617608, 9 pages, 2013.

[2] S. Wen and D. Wei, "The triple-parameters stochastic dynamics of ecological tourism system," Journal of Chemical and Pharmaceutical Research, vol. 6, no. 5, pp. 715-720, 2014.

[3] W. Shouwen, Research on the Educational Intervention of Visitors in Ecotourism Destinations, China Travel \& Tourism Press, Beijing, China, 2011.

[4] J. R. Pfafflin and E. N. Ziegler, Encyclopedia of Environmental Science and Engineering, CRC Press, New York, NY, USA, 2006.

[5] J. L. Marion and S. E. Reid, "Minimising visitor impacts to protected areas: the efficacy of low impact education programmes," Journal of Sustainable Tourism, vol. 15, no. 1, pp. 5-27, 2007.

[6] W. Wen, "Study progress of visitors' education both at home and abroad," Tourism Tribune, vol. 23, no. 7, pp. 92-96, 2008.

[7] S.-W. Wen and D. P. Wei, "Study on tourists' willingness to pay for educational services in sightseeing places," Economic Geography, vol. 32, no. 010, pp. 170-176, 2012. 
[8] Y. Li, L. Bangyi, and L. Weiguo, "Study on the strategy of product differentiation among travel agencies based on game theory," Management Review, vol. 22, no. 1, pp. 64-69, 2010.

[9] C.-Y. Yang, "Study on the vicissitude mechanism of managerial institution of China's tourism industry and the construction of multiple dynamic game model," Tourism Tribune, vol. 26, no. 6 , pp. 12-20, 2011.

[10] S. Yangping, "The utility analysis of governmental regulation on environmental protection program of eco-tourism based on the game theory," Ecological Industry Watch, no. 1, pp. 198-200, 2010.

[11] S. Liang, "Research on Chinese environment protection supervision mechanism: an evolutionary game theory analyses," Management Review, vol. 23, no. 8, pp. 46-51, 2011.

[12] C.-Y. Wang, "Study on formation mechanism of tourism model of village heritage sites based on muti-party game-a case study of Kaiping watchtower and villages," Mathmatics in Practice and Theory, vol. 43, no. 1, pp. 14-23, 2013.

[13] S.-Y. Xie, Economic Game Theory, pp. 146-165, Fudian University Press, Shanghai, China, 2006.

[14] S. Wen, "Effects of ecological educational on recreational impacts," Acta Ecologica Sinca, vol. 29, no. 2, pp. 768-775, 2009.

[15] Z. Ying, Game Theory and Information Economic, Shanghai People's Publishing House, 2004. 


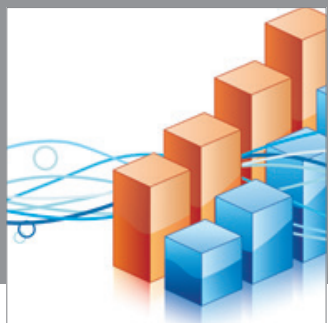

Advances in

Operations Research

mansans

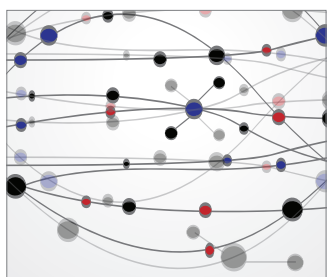

The Scientific World Journal
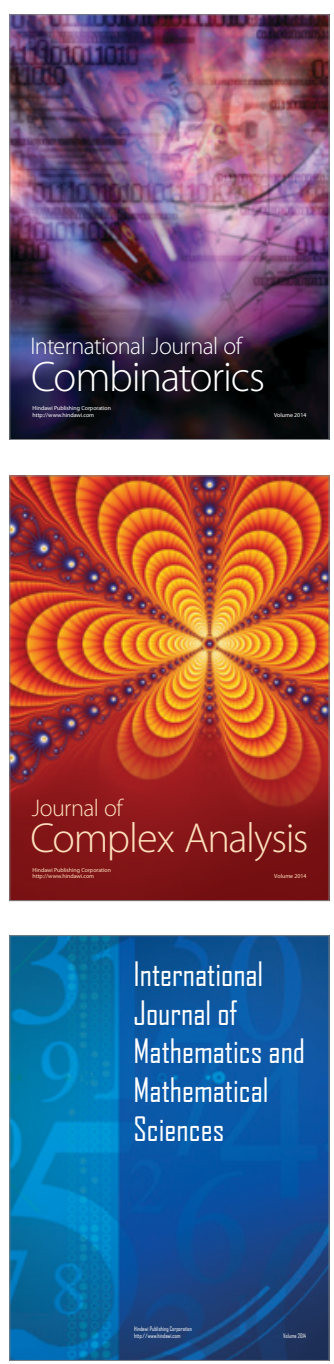
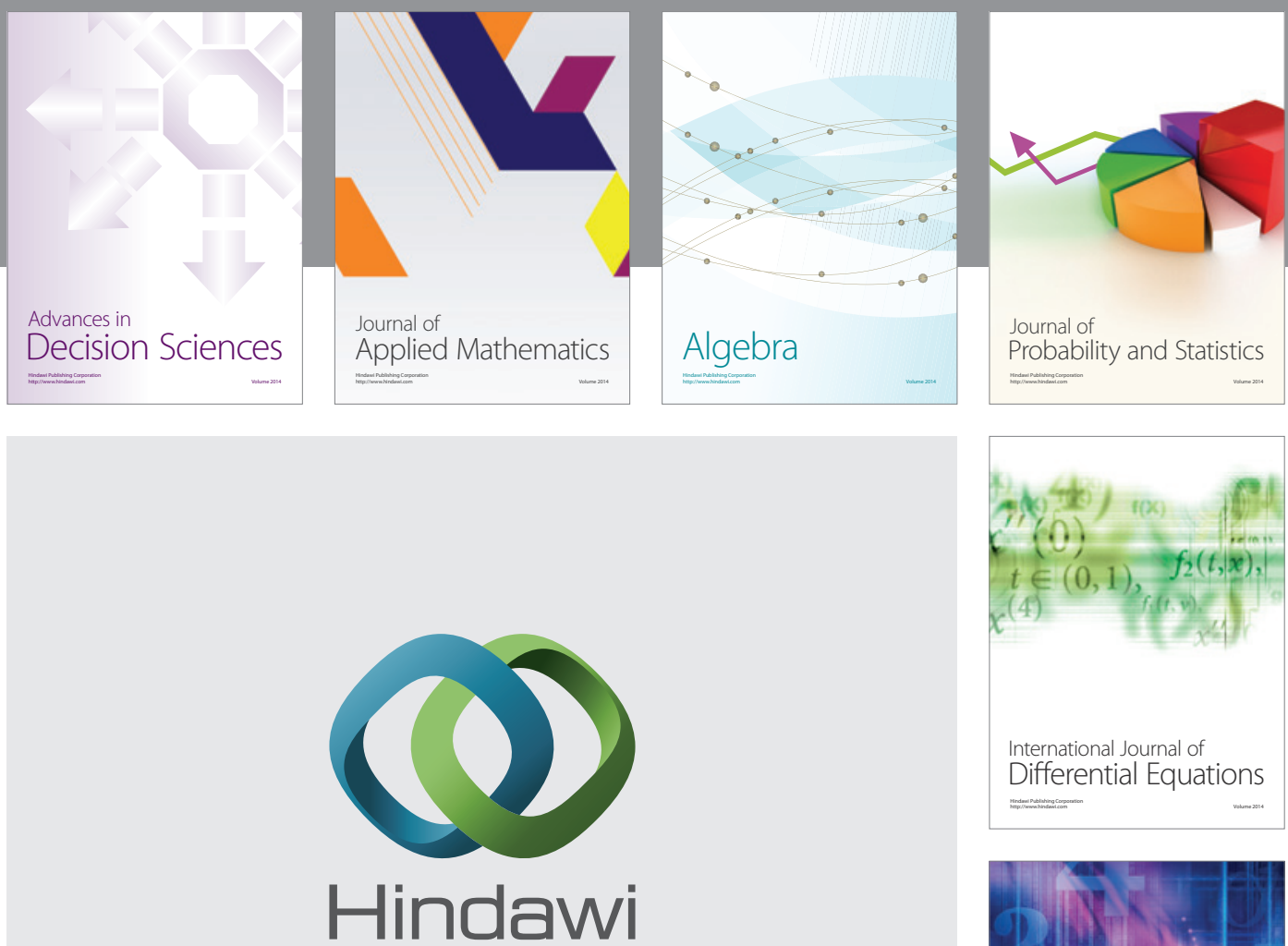

Submit your manuscripts at http://www.hindawi.com
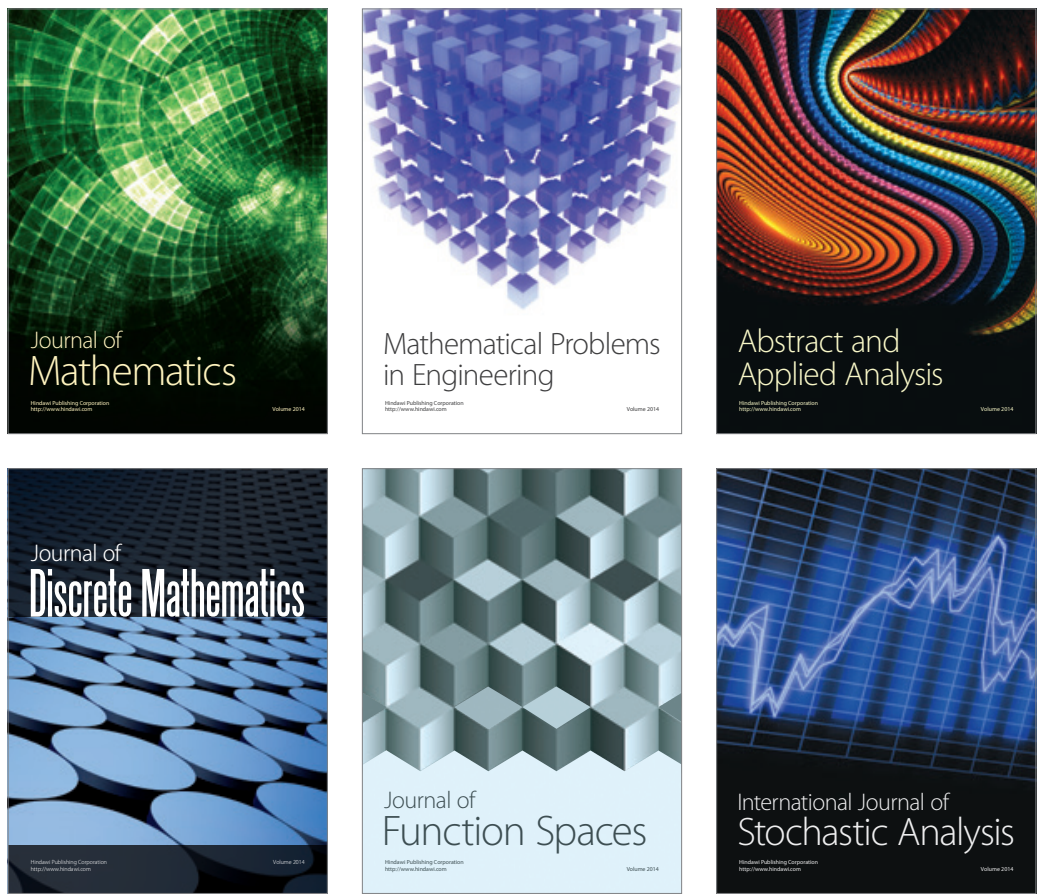

Journal of

Function Spaces

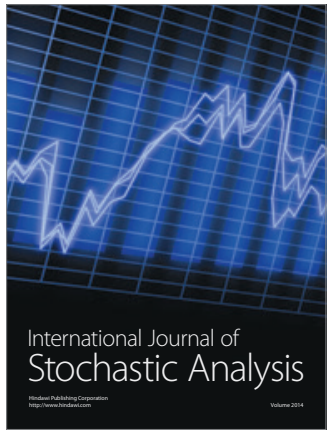

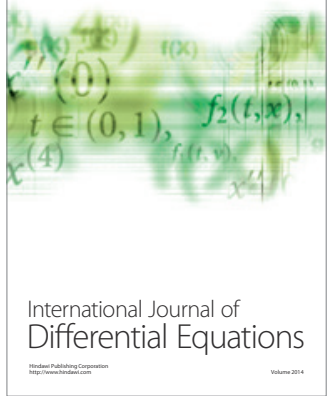
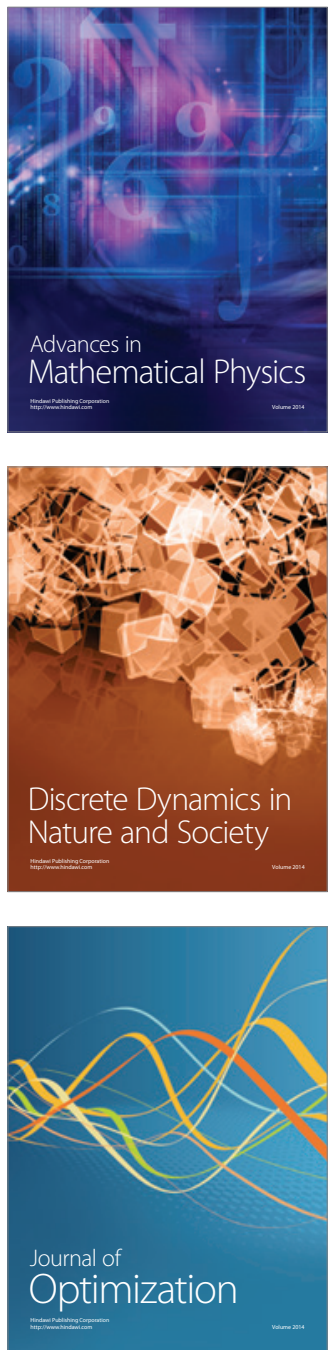